\title{
Observations of fluorescent and biological aerosol at a high-altitude site in central France
}

\author{
A. M. Gabey ${ }^{1}$, M. Vaitilingom ${ }^{2,3}$, E. Freney ${ }^{2}$, J. Boulon ${ }^{2}$, K. Sellegri ${ }^{2}$, M. W. Gallagher ${ }^{1}$, I. P. Crawford ${ }^{1}$, \\ N. H. Robinson ${ }^{4}$, W. R. Stanley ${ }^{5}$, and P. H. Kaye ${ }^{5}$ \\ ${ }^{1}$ School of Earth, Atmospheric and Environmental Science, University of Manchester, Manchester M13 9PL, UK \\ ${ }^{2}$ Laboratoire de Météorologie Physique, CNRS-Université Blaise Pascal, Observatoire de Physique du Globe, Aubière, France \\ ${ }^{3}$ Laboratoire de Synthèse Et Etude de Systèmes à Interets Biologique, CNRS-Université Blaise Pascal, France \\ ${ }^{4}$ Met Office, Exeter, UK \\ ${ }^{5}$ Centre for Atmospheric \& Instrumentation Research, University of Hertfordshire, Hertfordshire AL10 9AB, UK
}

Correspondence to: I. P. Crawford (i.crawford@manchester.ac.uk) and N. H. Robinson (niall.robinson@metoffice.gov.uk)

Received: 18 December 2012 - Published in Atmos. Chem. Phys. Discuss.: 30 January 2013

Revised: 17 June 2013 - Accepted: 27 June 2013 - Published: 2 August 2013

\begin{abstract}
Total bacteria, fungal spore and yeast counts were compared with ultraviolet-light-induced fluorescence (UV-LIF) measurements of ambient aerosol at the summit of the Puy de Dôme (PdD) mountain in central France (1465 m a.s.1), which represents a background elevated site. Bacteria, fungal spores and yeast were enumerated by epifluorescence microscopy (EFM) and found to number 2.2 to $23 \mathrm{~L}^{-1}$ and 0.8 to $2 \mathrm{~L}^{-1}$, respectively. Bacteria counts on two successive nights were an order of magnitude larger than in the intervening day.

A wide issue bioaerosol spectrometer, version 3 (WIBS3) was used to perform UV-LIF measurements on ambient aerosol sized 0.8 to $20 \mu \mathrm{m}$. Mean total number concentration was $270 \mathrm{~L}^{-1}\left(\sigma=66 \mathrm{~L}^{-1}\right)$, found predominantly in a size mode at $2 \mu \mathrm{m}$ for most of the campaign. Total concentration (fluorescent + non-fluorescent aerosol) peaked at $500 \mathrm{~L}^{-1}$ with a size mode at $1 \mu \mathrm{m}$ because of a change in air mass origin lasting around $48 \mathrm{~h}$. The WIBS-3 features two excitation and fluorescence detection wavelengths corresponding to different biological molecules, although non-biological interferents also contribute. The mean fluorescent particle concentration after short-wave $(280 \mathrm{~nm}$; associated with tryptophan) excitation was $12 \mathrm{~L}^{-1}\left(\sigma=6 \mathrm{~L}^{-1}\right)$, and did not vary much throughout the campaign. In contrast, the mean concentration of particles fluorescent after long-wave $(370 \mathrm{~nm}$; associated with NADH) excitation was $95 \mathrm{~L}^{-1}\left(\sigma=25 \mathrm{~L}^{-1}\right)$, and a nightly rise and subsequent fall of up to $100 \mathrm{~L}^{-1}$ formed a strong diurnal cycle in the latter. The two fluorescent
\end{abstract}

populations exhibited size modes at $3 \mu \mathrm{m}$ and 2 to $3 \mu \mathrm{m}$, respectively. A hierarchical agglomerative cluster analysis algorithm was applied to the data and used to extract different particle factors. A cluster concentration time series representative of bacteria was identified. This was found to exhibit a diurnal cycle with a maximum peak appearing during the day.

Analysis of organic mass spectra recorded using an aerosol mass spectrometer (AMS; Aerodyne Inc.) suggests that aerosol reaching the site at night was more aged than that during the day, indicative of sampling the residual layer at night. Supplementary meteorological data and previous work also show that PdD lies in the residual layer/free troposphere at night, and this is thought to cause the observed diurnal cycles in organic-type and fluorescent aerosol particles.

Based on the observed disparity between bacteria and fluorescent particle concentrations, fluorescent non-PBA is likely to be important in the WIBS-3 data and the surprisingly high fluorescent concentration in the residual layer/free troposphere raises questions about a ubiquitous background in continental air during the summer.

\section{Introduction}

Primary biological aerosol (PBA), the component of ambient aerosol that is discernibly composed of animal, plant or cellular material, is poorly quantified in the outdoor atmosphere. 
The reasons for this include the significant resources needed to collect and analyse samples, the need for many microbiologists to count only the living, reproducing (colony-forming) units, and also because "total PBA" counting techniques are difficult to reproduce, leading to large uncertainties.

Harrison et al. (2005) monitored year-round total bacteria concentrations at a coastal site in the UK, which was taken to represent a background concentration. Seasonal averages ranged from 2.8 to $13.9 \mathrm{~L}^{-1}$ (winter and autumn, respectively). They note the range of biological species was diverse and terrestrial in origin. Bauer et al. (2002) and MatthiasMaser et al. (2000) conducted winter PBA surveys at highaltitude sites in the Austrian and Swiss Alps, respectively. Both found typical bacteria concentrations of $10-50 \mathrm{~L}^{-1}$. Bauer et al. (2002) also reported mean fungal spore concentrations of $0.8 \mathrm{~L}^{-1}$. Since both sites were out of cloud and surrounded by snow-covered land when the samples were taken, the authors conclude the results are representative of the background PBA in Europe.

The use of aerosol spectrometers featuring light-induced fluorescence (LIF) and often ultraviolet-light-induced fluorescence (UV-LIF) for this purpose has been investigated in urban, suburban and desert environments in the USA by Pan et al. (2007); in tropical rainforest (Gabey et al., 2010; Huffman et al. 2011, 2013); Manchester, UK (Gabey et al., 2011); Mainz, Germany (Huffman et al., 2010); and Karlsruhe, Germany (Toprak and Schnaiter, 2013). Whilst false positives arise from aromatic hydrocarbons found in combustion aerosol and humic-like substances (HULIS) in some soil dusts, the merits of the technique are clear where PBA dominates the aerosol larger than $\sim 1 \mu \mathrm{m}$. Measuring additional particle properties such as size and morphology can also help ameliorate this problem by providing extra dimensions in which to distinguish different fluorescent particle types. Since previous studies were performed near source regions and close to sea level, an unreported aspect of ambient fluorescent aerosol is how strongly it contributes to the background aerosol. Information about the fluorescent aerosol at an elevated site can shed some light on the relative source strength at other locations by considering the possible levels of particle transport.

UV-LIF offers the possibility of near-instantaneous discrimination between PBA and other aerosol particles without the need for staining or incubation of the sample. It relies on intrinsically fluorescent molecules found in most living material including the amino acids tryptophan and Tyrosine ( $\lambda_{\text {excitation }} \sim 200$ to $300 \mathrm{~nm}$ ), flavins, and co-enzymes such as NADH ( $\lambda_{\text {excitation }} \sim 300$ to $400 \mathrm{~nm}$ ) and chlorophyll $\left(\lambda_{\text {excitation }} \sim 400\right.$ to $500 \mathrm{~nm}$ ). When present in a particle these compounds represent a few percent of the dry mass but dominate the fluorescence. It is, however, also susceptible to false positives from combustion aerosols and particles such as soil dust that contain humic-like substances (HULIS). These substances feature similar excitation and emission wavelengths to PBA (Pan et al., 2007; Merola et al., 2001). Therefore, whilst many developers of online fluorescence instrumentation often assume molecules such as NADH and tryptophan are responsible for the bulk of PBA fluorescence, based on mainly laboratory and short-term field tests with many individual biological systems (Li and Humphrey, 1991; Eng et al., 1989), and these are often reported as such in the literature (e.g. Huffman et al., 2010), the link to these specific molecules for ambient external and internal mixtures of aerosol has not been fully substantiated and the possible correlations remain to be proven by more detailed field validation. Therefore it is prudent that, in the following discussion and interpretation of aerosol fluorescent behaviour, the scientific community bears this caveat in mind.

No studies directly comparing microscopic and UV-LIF measurements of ambient aerosol appear in the literature, however such measurements have been performed separately in Mainz, Germany. Huffman et al. (2010) measured ambient particle fluorescence using an ultraviolet aerodynamic particle sizer (UV-APS; TSI Inc.), which employs a UV laser operating at NADH wavelengths. They attributed a fluorescent $\sim 3 \mu \mathrm{m}$ aerodynamic size mode to PBA, the occasional appearance of modes at larger sizes to pollen and spore release and a submicron mode to interferents from combustion aerosol. Median fluorescent number concentration in the $3 \mu \mathrm{m}$ mode was $16 \mathrm{~L}^{-1}$, and the fluorescent number fraction was 30 to $40 \%$ at $D_{\mathrm{A}}>3 \mu \mathrm{m}$. Matthias-Maser and Jaenicke (1995) report results of microscopically enumerated PBAP downwind of Mainz. PBA (mainly bacteria) accounted for approximately $50 \mathrm{~L}^{-1}$ (5 to $20 \%$ ) at $D>3 \mu \mathrm{m}$. This result is reasonably consistent with other cities. Bacteria concentrations in Birmingham, UK, and in Vienna, Austria, were found to be typically $\sim 10 \mathrm{~L}^{-1}$ (Harrison et al., 2005; Bauer et al., 2008); however, many more bacteria are found at smaller sizes in Mainz. The purpose of this study is to evaluate how the background fluorescent particle concentration matches bacteria and fungal spore counts in order to determine background concentrations before air from a major source (such as a city) is introduced.

\section{Materials and methods}

\subsection{Site description}

Measurements were performed at the summit of Puy de Dôme (PdD), in the Auvergne region of Central France $\left(45^{\circ} 26^{\prime} 20^{\prime \prime} \mathrm{N}, 2^{\circ} 57^{\prime} 57^{\prime \prime} \mathrm{E}, 1465 \mathrm{~m}\right.$ a.s.l. $), 16 \mathrm{~km}$ west of Clermont-Ferrand. Sunrise and sunset at the site were 06:00 and 21:40 (UTC+2), respectively. Measurements were performed during an unbroken out-of-cloud period that lasted from 22 June to 3 July 2010. The site lies in the residual layer/free troposphere at night and is typically found in the boundary layer for 5 to $6 \mathrm{~h}$ from 10:00 LT in the summer (Venzac et al., 2009). 
Vehicle activity at the summit was limited to authorised traffic accessing the measurement site or military installation bordering its northern edge. Occasional charcoal-burning and diesel generator tests were conducted in the vicinity. These events led to spikes in CPC, MAAP and gas-phase measurements being recorded at the site, but these could easily be excluded for the dataset, and do not appear in data concerning particles larger than $1 \mu \mathrm{m}$.

Aside from these events the site is consistent with a rural background, with median concentrations of $\mathrm{NO}_{\mathrm{X}}(\mathrm{NO}$ $\left.+\mathrm{NO}_{2}\right)=0.291 \mathrm{ppb}, \mathrm{SO}_{2}=1.7 \mathrm{ppb}$ and $\mathrm{O}_{3}=50 \mathrm{ppb}$ for the entire measurement period. Ultrafine aerosol concentration $(D>10 \mathrm{~nm})$, monitored by a condensation particle counter (TSI Inc, Model 3010), was typically 1000 to $4000 \mathrm{~cm}^{-3}$ during the campaign, which is typical of the site in the summer (Venzac et al., 2009). Ambient temperature ( $T$ ) rose steadily from daily minima of $4.5^{\circ} \mathrm{C}$ on 22 June to peaks of $\sim 17^{\circ} \mathrm{C}$ by 28 June, with a range of 5 to $8^{\circ} \mathrm{C}$ each day. Relative humidity (RH) ranged from 65 to $85 \%$, highest when the temperature was coolest. This RH cycle broke down because of a moist air mass influencing the site on 29 and 30 June, when RH was typically 80 to $90 \%$ throughout.

Hourly air mass back trajectories of $72 \mathrm{~h}$ length ending at PdD were calculated using the HYSPLIT trajectory model. The period from 22 to 29 June is dominated by E/NE air masses, 29 to 30 June features a transition to a northerly air mass and 1 to 2 July is characterised by trajectories passing over the NW of France. Marinoni et al. (2004) report that easterly air masses arriving at $\mathrm{PdD}$ are anthropogenically influenced continental air, northwesterly air masses are continental/marine background and northerly air masses are anthropogenically influenced by urban areas in the north of France.

\subsection{Inlet configuration}

Instruments sampled downstream of a whole air inlet (WAI; Sellegri et al., 2003), which samples at approximately $100 \mathrm{~L} \mathrm{~min}^{-1}$, leading to a $30 \mu \mathrm{m}$ upper size cut for wind speeds of $6 \mathrm{~m} \mathrm{~s}^{-1}$. The inlet is internally maintained at $25^{\circ} \mathrm{C}$ when negative temperatures occur internally. Internal $\mathrm{RH}$ was 20 to $30 \%$ lower than the external ambient RH. Logistical constraints meant that the wide issue bioaerosol spectrometer, version 3 (WIBS-3), was connected to two different inlets: one on a nearby structure for the first $48 \mathrm{~h}$ of the campaign, and the WAI on the facility rooftop for the remainder. A 13-stage low-pressure cascade impactor (ELPI) sampled from the WAI at $30 \mathrm{~L} \mathrm{~min}^{-1}$ from 25 to 28 June (NE air masses). A $2 \mathrm{~h}$ comparison between rooftop and WAI air for the latter installation was conducted using one aerodynamic particle sizer (TSI Inc, APS model 3321). This consisted of four 30 min measurements alternating between positions, and showed that inlet efficiency was approximately 1 for the aerodynamic size range $0.9<D_{\mathrm{A}}<10 \mu \mathrm{m}$, although this is more uncertain at larger sizes because of the duration of the intercomparison. The APS ran alongside the WIBS-3 for the rest of the campaign.

\subsection{Epifluorescence microscopy}

Black Millipore ${ }^{\circledR}$ filters (GTBP filter, porosity $0.22 \mu \mathrm{m}$, diameter $25 \mathrm{~mm}$ ) were placed on the first five ELPI stages, which have cut-off diameters $\left(D_{50 \%}\right)$ at 9.9, 6.8, 4.4, 2.5 and $1.6 \mu \mathrm{m}$ (Sellegri et al., 2003). The samples were refrigerated at $5{ }^{\circ} \mathrm{C}$ before enumeration, which took place within one week of sample collection. Before enumeration each filter was stained using $100 \mu \mathrm{L}$ of 4',6-diamino-2-phenylindol (DAPI; Porter and Feig, 1980) solution $\left(25 \mu \mathrm{gL}^{-1}\right)$ and placed in darkness at $20^{\circ} \mathrm{C}$ for $20 \mathrm{~min}$. After this fixing process, filters were rinsed with $20 \mathrm{~mL}$ of sterile filtered ultrapure water $(0.22 \mu \mathrm{m}$ porosity) using vacuum filtration, then mounted on microscope slides and observed under epifluorescence microscopy $(\mathrm{EFM})\left(\lambda_{\text {excitation }}=365 \mathrm{~nm}, \lambda_{\text {emission }}=\right.$ $420 \mathrm{~nm})$.

At least 30 fields of view per filter (1000 magnification) were used to count bacteria and at least 20 fields (400 magnification) for yeasts, fungal spores, pollen and plant debris. The estimated counting uncertainty based on these parameters is $25 \%$ for bacteria and $20 \%$ for spores and yeasts. EFM is also subject to uncertainties from recognition errors and non-specific staining (Eduard, 2001; Eduard and Heederik, 1998).

Four size-segregated cascade impactor samples were obtained at the times set out in Table 1. Concentrations were estimated by calculating the volume of air that passed through the observed area of each filter and dividing the total number of bacteria by this number.

\subsection{WIBS-3 bioaerosol spectrometer}

\subsubsection{Instrument description}

The WIBS- 3 is a single-particle UV-induced fluorescence (UV-IF) spectrometer (Gabey et al., 2010; Foot et al., 2008; Kaye et al., 2005). It excites and detects fluorescence in particles sized 0.8 to $20 \mu \mathrm{m}$ at wavelengths dominated by two molecules common in biological material: the amino acid tryptophan and the co-enzyme NADH. Other amino acids and flavins are also exhibit weaker fluorescent at these wavelengths (Lakowicz, 2006). The operating principle of the instrument is described in detail by Kaye et al. (2005), and so will only briefly be summarised here. Fluorescence in single aerosols is induced using a UV pulse from a xenon discharge lamp centred at $280 \mathrm{~nm}$, and the intensity in the wavelength range 310 to $400 \mathrm{~nm}$ is recorded. This is generally assumed to be associated with tryptophan-like molecules. Any additional fluorescence intensity arising from this first excitation pulse is simultaneously recorded between 400 and $600 \mathrm{~nm}$. Fluorescence is also induced by an excitation centred at $370 \mathrm{~nm}$ and whose intensity is again recorded in this second band, 
Table 1. Filter sample times and durations, ELPI concentration results and corresponding WIBS and APS mean number concentrations.

\begin{tabular}{ccccccccc}
\hline $\begin{array}{c}\text { Start } \\
\text { time (LT) }\end{array}$ & $\begin{array}{c}\text { Duration } \\
(\mathrm{h})\end{array}$ & $\begin{array}{c}\text { Spores, yeast } \\
\left(\mathrm{L}^{-1}\right)\end{array}$ & $\begin{array}{c}\text { Bacteria } \\
\left(\mathrm{L}^{-1}\right)\end{array}$ & $\begin{array}{c}\overline{N_{\mathrm{APS}}} D_{\mathrm{A}} \geq 2 \mu \mathrm{m} \\
\left(\mathrm{L}^{-1}\right)\end{array}$ & $\begin{array}{c}\overline{N_{\text {WIBS }}} D_{\mathrm{A}} \geq 1 \mu \mathrm{m} \\
\left(\mathrm{L}^{-1}\right)\end{array}$ & $\overline{N_{\mathrm{TRY}}}$ & $\overline{N_{\mathrm{NADH}}}$ \\
\hline $\mathrm{A}$ & 25 Jun, 15:00 & 24 & 0.78 & 3.4 & 238 & 230 & 9.7 \\
$\mathrm{~B}$ & 27 Jun, 00:00 & 7 & 1.5 & 33 & 175 & 178 & 89.9 & 105.2 \\
$\mathrm{C}$ & 27 Jun, 08:00 & 10 & 1.3 & 2.2 & 173 & 172 & 11 & 81.8 \\
$\mathrm{D}$ & 27 Jun, 19:00 & 14 & 2.7 & 22 & 153 & 168 & 10.6 & 97.8 \\
\hline
\end{tabular}

400 to $600 \mathrm{~nm}$. Many laboratory tests involving individual PBA types show that fluorescence here is usually associated with $\mathrm{NADH}$ fluorescence rather than tryptophan $(\mathrm{Li}$ and Humphrey, 1991; Eng et al., 1989). Terminology associated with PBA and fluorescence properties aerosol is complex and often lacking consensus, however, for simplicity, the variables $N_{\text {TRY }}$ and $N_{\mathrm{NADH}}$ refer to the concentration of fluorescent particles associated with the two wavelength channels described here. It should not be assumed, however, that UV-LIF observations reported for ambient aerosol for these wavelength regions are only associated with these specific molecules. As in many other areas of organic aerosol chemistry, we will adopt a more generic terminology whereby it will be implicit that we are referring to "NADH-like" or "tryptophan-like" molecules as being responsible for the fluorescence signatures as other biological as well as nonbiological molecules may also contribute as discussed in the previous references. One of the aims of this work is to challenge the robustness of the common assumption in the use of certain commercial LIF instruments of the link between $N_{\mathrm{NADH}}$ and bacterial count, for example, and whether this is justified.

In addition, the WIBS instrument also records the intensity of forward and side-scattered light when each particle passes through the particle detection system (based on a $632 \mathrm{~nm}$ continuous wave diode laser beam) used for triggering the UV excitation pulses. These values are compared to a lookup table generated by a Mie scattering model calibrated using polystyrene latex microspheres (Polyscience Inc.) to provide an estimate of particle optical equivalent diameter $\left(D_{\mathrm{P}}\right)$. The forward-scattering detector is additionally split into four quadrants that separately record intensity, quantifying the asymmetry factor (AF) of the scattering pattern. The morphology of a particle affects this pattern (Aptowicz et al., 2006) and AF in turn provides rudimentary information about the relative shape of each particle in an aerosol population. In this work we will refer only briefly to this aspect of the data to highlight general relative changes in particle morphology. Intercomparison between the WIBS-3 and an aerodynamic particle sizer (APS, TSI Inc, Model 3321) at PdD showed good agreement within the instrumental uncertainty that $N_{\text {WIBS }}\left(D_{\mathrm{P}}>1 \mu \mathrm{m}\right) N_{\mathrm{APS}}\left(D_{\mathrm{A}}>2 \mu \mathrm{m}\right)$ with $r=0.77$. Further comparisons between the WIBS and a single UV channel TSI UV-APS (N. H. Robinson and J. A. Huffman, personal communication, 2011) for the common NADH-like fluorescent channel has also showed encouraging agreement (to be reported separately).

\subsubsection{WIBS-3 data quality control}

The fluorescence detection protocol used was similar to that discussed in Gabey et al. (2010), although the internal fluorescence of the instrument is now measured automatically every $3 \mathrm{~h}$ to ensure that a change in the baseline does not affect the results. This threshold procedure allows $0.1 \%$ of non-fluorescent particles to be misclassified as fluorescent. Particles that do not exceed the threshold in any of the three channels were classified as non-fluorescent. Instrument calibration and optical alignment of the fluorescence components were verified at the beginning of the experiment using $1 \mu \mathrm{m}$ and $2.1 \mu \mathrm{m}$ blue-fluorescent and non-fluorescent PSL microspheres (Duke Scientific, Inc). The WIBS-3 inlet flow rate was periodically verified to be $2.38 \mathrm{~L} \mathrm{~min}^{-1} \pm 5 \%$ using a mass flow meter, and an averaging time of 15 min was employed when deriving number concentrations. This is longer than that used previously in tropical rainforest because of the lower particle concentration at PdD.

\subsection{Aerosol mass spectrometer}

The chemical composition and mass concentration of the non-refractory submicron particulate matter $\left(\mathrm{NR}-\mathrm{PM}_{1}\right)$ was measured with an Aerodyne time-of-flight mass spectrometer (ToF-AMS) (DeCarlo et al., 2006; Canagaratna et al.). In order to extract chemically resolved mass concentrations of individual species, the AMS raw data are evaluated with standard assumptions as described by Allan et al. (2004). The resolved mass concentrations included ammonium, sulfate, nitrate, organic and chloride species. The aerosol was not dried before being sampled, and the instrument operated behind an interstitial inlet designed to transmit only non-activated particles when the site was in cloud.

A collection efficiency (CE) was be applied to AMS mass spectra data in order to calculate mass concentrations. This is defined as the fraction of the particle mass that is measured by the AMS, relative to what would be measured if all particles were spherical and particle bounce was negligible. The aerosol composition was dominated by organics and $\mathrm{SO}_{4}$ and the aerosol was always neutralised, so a CE of 0.5 is suitable 
at this site. This was assessed by comparing the total volume of black carbon and AMS-measured aerosol with that sampled by a scanning mobility particle sizer (SMPS). Deconvolution of the organic signal from the AMS was carried out using positive matrix factorisation (PMF).

\section{Results}

\subsection{Epifluorescence microscopy results}

Out of the four cascade impactor runs, one was performed during $24 \mathrm{~h}$ (sample A), two were sampled exclusively during night-time (samples B and D) and one was sampled during daytime (sample C). For each sample, the first five impaction stages were analysed, but biological material was detected exclusively on the two uppermost stages $\left(D_{50 \%}=6.8 \mu \mathrm{m}\right)$ in samples A-C, and the three uppermost stages $\left(D_{50 \%}=4.4 \mu \mathrm{m}\right)$ in sample D. Counts were dominated by microorganisms found on the first $\left(D_{50 \%}=9.9 \mu \mathrm{m}\right)$ stage in all cases, with $2-36 \%$ of this number found on the second stage.

The concentrations of fungal spores and yeasts are laid out for each sample in Table 1 . The spore/yeast concentration ranges from 0.8 to $2.7 \mathrm{~L}^{-1}$ over the four samples, and the bacteria from 3.4 and $2.2 \mathrm{~L}^{-1}$ in samples $\mathrm{A}$ and $\mathrm{C}$ to 33 and $22 \mathrm{~L}^{-1}$ in samples $\mathrm{B}$ and $\mathrm{D}$. This indicates a strong nighttime increase in bacteria concentration at $\mathrm{PdD}$; however, the mean bacteria concentration in sample A ( $24 \mathrm{~h}$ duration) does not suggest such an increase took place on the evening of 25 to 26 June.

Whilst quantitative size information is not available from the filter data, most of the bacterial cells collected seem to be cocci bacteria (spherical shape) with diameter of 0.5 to $2 \mu \mathrm{m}$. And a smaller number of the bacteria collected have a rodlike shape (bacilli) of 2 to $5 \mu \mathrm{m}$ in length. Elliptical fungi and yeasts were typically $\sim 10$ to $30 \mu \mathrm{m}$ in size and mainly found on the first $\left(D_{50 \%}=9.9 \mu \mathrm{m}\right)$ stage.

\subsection{WIBS results}

Total, non-fluorescent and fluorescent particle concentrations obtained using the WIBS-3 are plotted in Fig. 1i to iv. Total WIBS-3-recorded number $\left(N_{\mathrm{TOT}}\right)$ ranges from 200 to $400 \mathrm{~L}^{-1}$ throughout the campaign, with its variation primarily governed by non-fluorescent $\left(N_{\mathrm{NON}}\right)$ particles and those with NADH-like fluorescence $\left(N_{\mathrm{NADH}}\right)$ at different times of day. $N_{\text {NON }}$ was typically 100 to $300 \mathrm{~L}^{-1}$ and $N_{\text {NADH }}$ was 40 to $150 \mathrm{~L}^{-1}$, with strong enhancements on some evenings. For clarity, "enhanced" $N_{\mathrm{NADH}}$ periods are defined as 23:00 to 06:00 LT, 22 to 28 June, and the intervening "non-enhanced" times are 10:00 to 20:00 LT, 22 to 27 June. Particles with tryptophan-like fluorescence $\left(N_{\mathrm{TRY}}\right)$ are much less abundant, numbering 8 to $20 \mathrm{~L}^{-1}$. $N_{\mathrm{NADH}}$, and $N_{\mathrm{TRY}}$ to a lesser degree, increases steadily through the campaign, and $N_{\mathrm{NADH}}$ usually increases after dark before reducing again by sunrise.

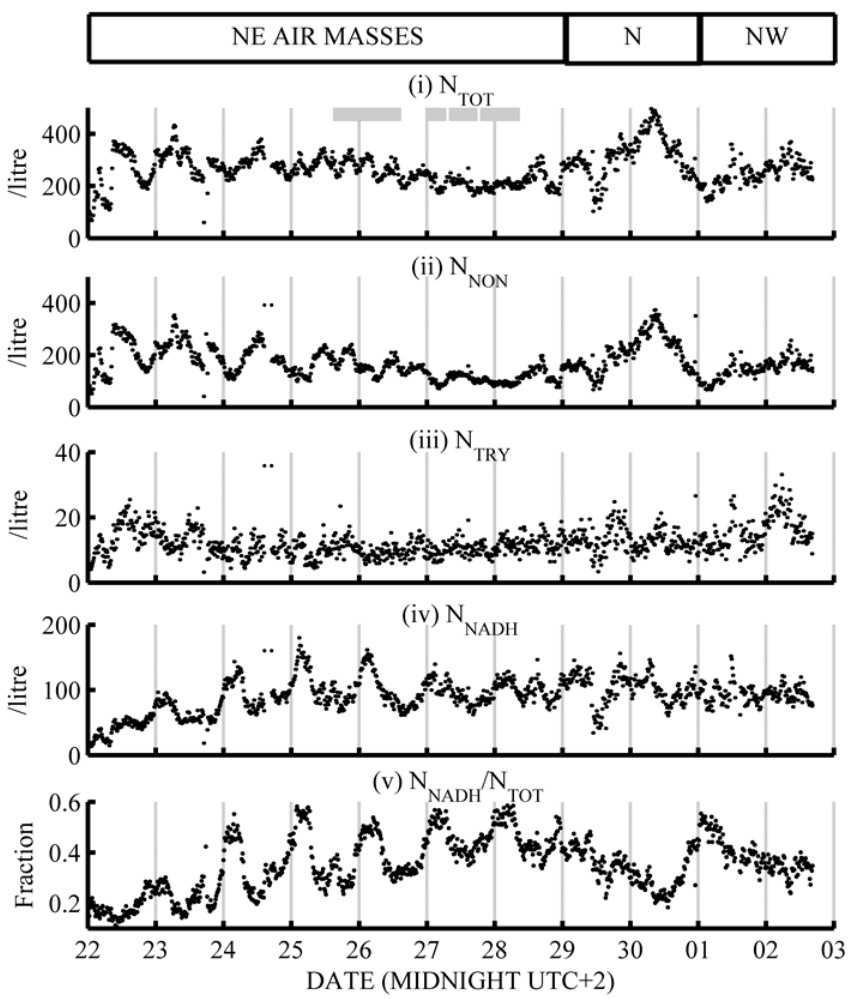

Fig. 1. (i to iv) WIBS-3 number concentrations of fluorescent and non-fluorescent particle types (v) number fraction of $N_{\mathrm{NADH}}$ and relative humidity time series from 22 June to 3 July 2010. Grey boxes denote when ELPI samples were running and white boxes show modelled air mass origin.

Particles exhibiting both types of fluorescence $\left(N_{\text {BOTH }}\right)$ are strongly correlated to $N_{\mathrm{TRY}}$ and represent around $75 \%$ of $N_{\text {TRY }}$.

The data can be split into three periods based on modelled air mass origin. Table 2 lists the correlation coefficients between different components of $N_{\text {TOT }}$ during these periods. Median aerosol particle size distributions $\left(\mathrm{d} N / \mathrm{d} \log D_{\mathrm{P}}\right)$ of each component are plotted in Fig. $2 \mathrm{i}$ to iii in order to compare periods of $N_{\mathrm{NADH}}$ enhancement and different air mass influences. Over the entire campaign the primary $N_{\mathrm{TOT}}$ size mode (Fig. 2i) was at $2 \mu \mathrm{m}$. Non-fluorescent and fluorescent particles contribute at this size, with the $N_{\mathrm{NON}}$ size distribution bimodal at 1 and $2 \mu \mathrm{m}$, dominating the $N_{\text {TOT }}$ mode at $1 \mu \mathrm{m}$. Median $N_{\mathrm{NADH}}$ distributions (Fig. 2ii) for the campaign peak at 2 to $3 \mu \mathrm{m}$, dominating $N_{\text {TOT }}$ here. The $N_{\text {TRY }}$ size spectra (Fig. 2iii) consistently peak at 2 to $3 \mu \mathrm{m}$ regardless of the $N_{\mathrm{NADH}}$ enhancements.

\subsubsection{2 to 29 June}

The first week of measurements was associated with air masses arriving from the NE of France. $N_{\text {TOT }}$ ranges from 200 to $400 \mathrm{~L}^{-1}$ in a diurnal cycle that peaks close to midday (local time) and was driven by $N_{\text {NON }}$ from 22 to 25 June. 
Table 2. Correlation coefficients $(r)$ between WIBS-3 number concentrations, broken down by (i) modelled air mass origin and (ii) times of non-enhanced and enhanced $N_{\mathrm{NADH}} / N_{\mathrm{TOT}}$ from 22 to 29 June, which are taken to be 10:00 to 20:00 LT and 23:00 to 06:00 LT, respectively.

\begin{tabular}{lrrrrr}
\hline$r(x, y)$ & NE & N & NW & $\begin{array}{r}\text { NE, non-enhanced } \\
N_{\text {NADH }}\end{array}$ & $\begin{array}{r}\text { NE, enhanced } \\
N_{\text {NADH }}\end{array}$ \\
\hline$r\left(N_{\mathrm{TOT}}, N_{\text {NON }}\right)$ & 0.87 & 0.97 & 0.96 & 0.91 & 0.88 \\
$r\left(N_{\mathrm{TOT}}, N_{\text {NADH }}\right)$ & 0.20 & 0.68 & 0.56 & 0.49 & 010 \\
$r\left(N_{\mathrm{TRY}}, N_{\mathrm{NADH}}\right)$ & 0.13 & 0.53 & 0.49 & 0.49 & -0.17 \\
$r\left(N_{\mathrm{NADH}}, N_{\mathrm{NON}}\right)$ & -0.31 & 0.49 & 0.31 & 0.08 & -0.39 \\
$r\left(N_{\mathrm{TRY}}, N_{\mathrm{NON}}\right)$ & 0.41 & 0.37 & 0.63 & 0.53 & 0.33 \\
\hline
\end{tabular}
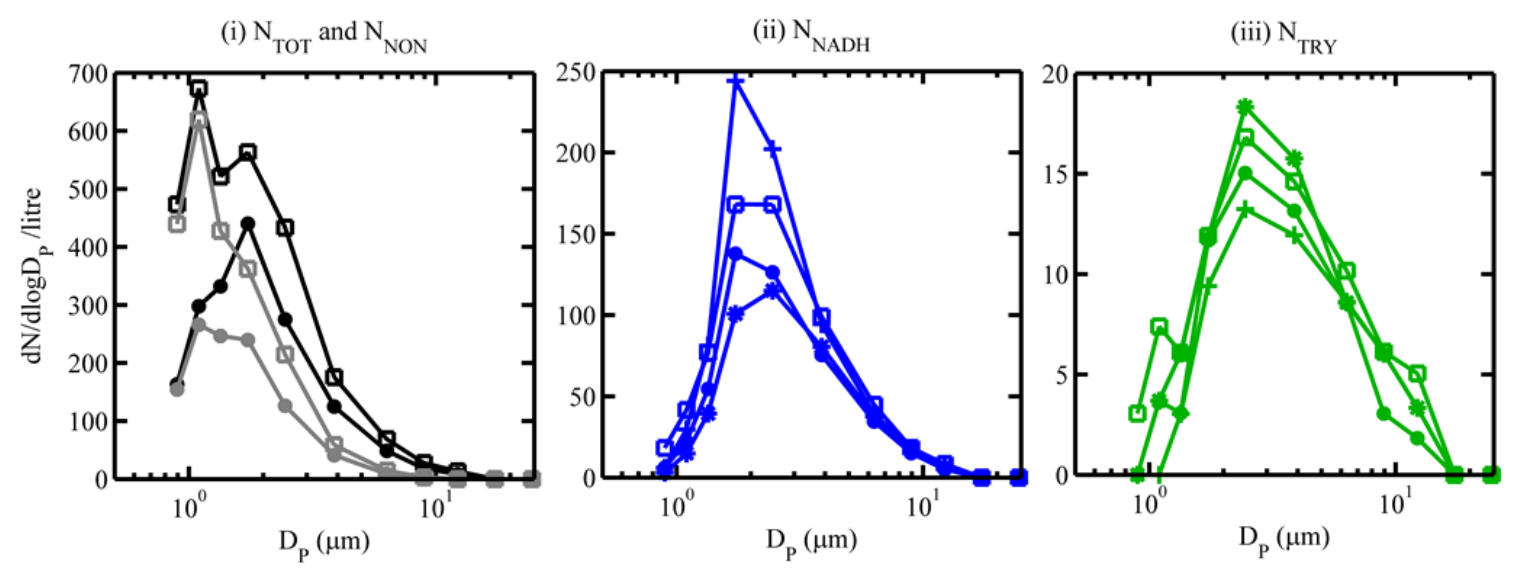

Fig. 2. Median number size distributions for different WIBS-3 concentrations broken down by periods of different influence. Solid circle: median for entire campaign; square: during $N$ air mass; $(*)$ : between NNADH enhancements; (+): during NNADH enhancements.

After 25 June $N_{\text {TOT }}$ peaks at local midnight, with this feature caused by a daily rise in $N_{\mathrm{NADH}}$ of 50 to $100 \mathrm{~L}^{-1}$ that offsets the nocturnal fall in $N_{\mathrm{NON}}$. The reverse happens in the daytime so that $N_{\text {TOT }}$ was maintained at a consistent level throughout the week. $N_{\mathrm{NADH}}$ was anti-correlated with $N_{\mathrm{NON}}$ overall during the first week, with a weak positive correlation in the daytime and strong negative correlation at night (Table 2). $N_{\text {NADH }}$ rises steadily from $10 \mathrm{~L}^{-1}$ on 22 June (following several days of cloud and rain) to $\sim 100 \mathrm{~L}^{-1}$ on 29 June.

$N_{\text {TRY }}$ remains at 10 to $20 \mathrm{~L}^{-1}$ throughout the first week, with slight decreases at night causing a negative correlation with $N_{\mathrm{NADH}}$. Both $N_{\mathrm{TRY}}$ and non-enhanced $N_{\mathrm{NADH}}$ were consistent day-to-day, with small increases in number in the afternoon. The enhancements in $N_{\mathrm{NADH}}$ become clearer when the ratio $N_{\mathrm{NADH}} / N_{\mathrm{TOT}}$ was calculated (Fig. 1 $1 \mathrm{v})$, illustrating that the smaller increases in $N_{\mathrm{NADH}}$ from 26 to 29 June still represent a large change in number fraction because of the reductions in $N_{\mathrm{NON}}$ at night. Comparing the modal $N_{\mathrm{NADH}}$ size distributions during and between enhancements (Fig. 2ii) reveals a rise in the number of 1.5 to $2 \mu \mathrm{m}$ fluorescent particles during enhancements, compared with the 2 to $3 \mu \mathrm{m}$ particles that dominate at intervening times. Median $N_{\mathrm{TRY}}$ is lower during $N_{\mathrm{NADH}}$ enhancements and higher during non-enhanced $N_{\mathrm{NADH}}$, which reflects the negative correlation between the two particle types from 22 to 29 June.

\subsubsection{June to 1 July}

A change to northerly air masses that pass close to urban and industrial regions initially sees $N_{\mathrm{TOT}}, N_{\mathrm{NADH}}$ and $N_{\mathrm{NON}}$ fall before $N_{\mathrm{NON}}$ increases to its campaign maximum of $300 \mathrm{~L}^{-1}$. After the initial reduction in number, $N_{\mathrm{NADH}}$ recovers to its previous value of $100 \mathrm{~L}^{-1}$, but unlike $N_{\mathrm{NON}}$ it did not continue to climb, leading to a suppressed $N_{\mathrm{NADH}} / N_{\mathrm{NON}}$ fraction and a weaker diurnal feature on the evening of 30 June than previously. In this $N_{\mathrm{NON}}$-dominated regime $N_{\mathrm{TOT}}, N_{\mathrm{NADH}}$ and $N_{\mathrm{TRY}}$ correlate positively with one another (Table 2) because of the common periods of reduction and recovery. $N_{\text {TOT }}$ and $N_{\text {NON }}$ rise strongly at $1 \mu \mathrm{m}$ (Fig. $2 \mathrm{i}$ ) in this period, but the $2 \mu \mathrm{m}$ fluorescent mode remains comparable in strength to when NE air masses arrived at the site. In line with its consistent number concentration $\mathrm{d} N_{\mathrm{TRY}} / \mathrm{d} \log D_{\mathrm{P}}$ does not exhibit new features through the campaign.

\subsubsection{1 to 2 July}

As NW air masses reach the site, $N_{\mathrm{NON}}$ returns to 100 to $200 \mathrm{~L}^{-1}, N_{\mathrm{NADH}}$ was typically $100 \mathrm{~L}^{-1}$, and the size distributions more closely resemble those observed during the NE influence than during the northerly influence. Strong increases in $N_{\mathrm{NADH}}$ at night are not observed, but reductions in $N_{\text {NON }}$ at these times still cause the $N_{\mathrm{NADH}}$ number fraction 

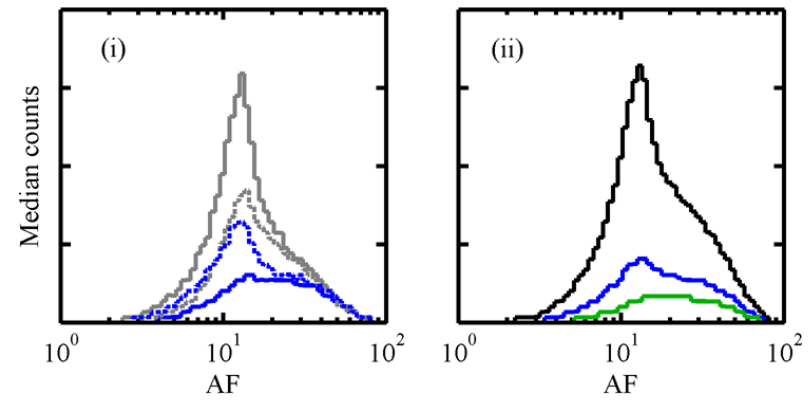

Fig. 3. Median asymmetry factor (AF) histograms (i) of $N_{\mathrm{NON}}$ (grey) and $N_{\mathrm{NADH}}$ (blue) during enhanced $N_{\mathrm{NADH}}$ (dashed) and intervening periods (solid), and (ii) $N_{\mathrm{TOT}}$ (black), $N_{\mathrm{NADH}}$ and $N_{\mathrm{TRY}}$ (green) through the period 22 to 29 June 2010.

to increase to $\sim 50 \%$ on the evening of 1 to $2 \mathrm{July}$, but both remain steady the following evening, and no enhancement takes place. $N_{\mathrm{TRY}}$ reaches its campaign maximum of $30 \mathrm{~L}^{-1}$ (10\% of $N_{\text {TOT }}$ ) at 04:00 on 2 July before returning to $10 \mathrm{~L}^{-1}$ at the end of measurements. The time series of $N_{\mathrm{TRY}}, N_{\mathrm{NADH}}$ and $N_{\mathrm{NON}}$ each have some common features in this period, and as a result they are mutually positively correlated.

\subsubsection{AF measurements}

Asymmetry factor distributions $(\mathrm{d} N / \mathrm{d} \log \mathrm{AF})$ are plotted in Fig. 3 for different $N_{\text {TOT }}$ components from 22 to 29 June. This period was selected because the northerly air mass (29 June onward) introduces a broad, mono-modal AF distribution that obscures bimodality in the data which is now discussed. Figure $3 \mathrm{i}$ shows $N_{\text {TOT }}$ peaks primarily at $\mathrm{AF}=11$, and is broadened by fluorescent material with larger AF. $N_{\mathrm{NADH}}$ features a primary mode at $\mathrm{AF}=11$ during enhancements, and a secondary mode at $\mathrm{AF}=20$ with a broader distribution. Between enhancements (Fig. 3i) the low-AF mode vanishes and $N_{\mathrm{NADH}}$ is mono-modal at $\mathrm{AF}=20$. The $N_{\mathrm{NON}}$ distribution peaks at $\mathrm{AF}=11$ regardless of $N_{\mathrm{NADH}}$ enhancements, and like $N_{\mathrm{NADH}}$ it also has a contribution from higherAF particles. Median AF distributions of $N_{\text {TOT }}, N_{\mathrm{NADH}}$ and $N_{\text {TRY }}$ for 22 to 29 June are printed in Fig. 3ii. The $N_{\text {TRY }}$ mode is consistently found at $\mathrm{AF}=20$, with a small feature at $\mathrm{AF}=11$ that is likely to arise from the small proportion of non-fluorescent particles that are misclassified as fluorescent.

The contribution of high-AF and low-AF particles to $N_{\mathrm{NADH}}$ and $N_{\mathrm{NON}}$ can be estimated by fitting a bimodal Gaussian curve to the median distributions and calculating the area under each, although the small number concentration makes it difficult to resolve these features temporally. $N_{\mathrm{NADH}}$ splits almost evenly between the two modes, while $30 \%$ and $70 \%$ of $N_{\mathrm{NON}}$ was high-AF and low-AF, respectively. A total of six particle types are therefore distinguishable in the WIBS-3 data, based on which channels detect fluorescence and the relative strength of the AF mode.

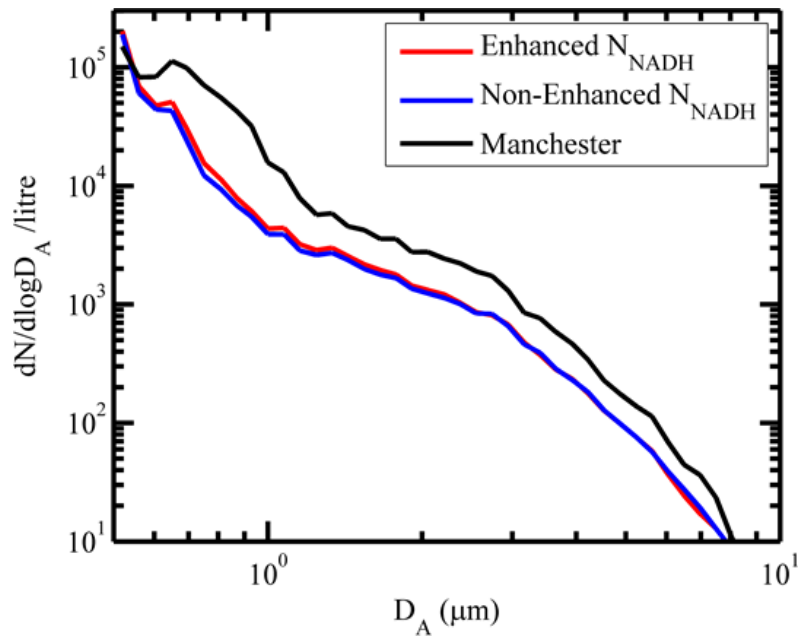

Fig. 4. Median APS aerosol number size distributions during $N_{\mathrm{NADH}}$ enhancements and the intervening times compared with typical urban results from Manchester.

\subsection{APS number concentration}

Median aerosol particle size distributions from the APS are plotted in Fig. 4 during periods of enhanced and non-enhanced $N_{\mathrm{NADH}}$. The distribution from an afternoon in Manchester, UK (4 June 2010, 10:45 to 13:00 LT), is also included to illustrate that number concentrations are smaller at PdD than in an urban location. Median $N_{\mathrm{APS}}$ at $0.72 \leq D_{\mathrm{A}} \leq 0.78 \mu \mathrm{m}$ outside of $N_{\mathrm{NADH}}$ enhancements is $20 \%$ smaller than during enhancements; however, these differences are unlikely to affect the WIBS- 3 counts because $N_{\text {TOT }}$ most closely matches $N_{\text {APS }}\left(D_{\mathrm{A}} \geq 2 \mu \mathrm{m}\right)$, with a large difference at smaller sizes.

Mean $N_{\mathrm{APS}}(D \geq 2 \mu \mathrm{m})$ corresponding to the impactor sampling times are printed alongside the other results in Table 1 (mean is used rather than median to match the cell count calculations). Like $N_{\text {TOT }}$ it declines progressively with each successive impactor sample. $\overline{N_{\mathrm{APS}}}\left(D_{\mathrm{A}} \geq 2 \mu \mathrm{m}\right)$ was larger during sample $\mathrm{C}$ than during sample $\mathrm{D}$ and comparable during samples B and C. $\overline{N_{\mathrm{APS}}}\left(0.54 \leq D_{\mathrm{A}} \leq 2 \mu \mathrm{m}\right)$ also reduces in all size bins as the impactor samples progress, indicating the underlying downward trend in aerosol concentration at this time.

\section{Discussion}

\subsection{Possible influences on the aerosol at PdD}

Given the consistent underlying trend of $N_{\mathrm{NADH}}$ throughout the campaign, it is thought that it was independent of the observed air masses origin. Urban WIBS- 3 measurements (Manchester, UK) exhibit a strong fluorescent primary size mode at $1 \mu \mathrm{m}$ (Gabey et al. (2011); Fig. 5i), whereas at PdD the primary $N_{\mathrm{NADH}}$ mode was at 2 to $3 \mu \mathrm{m}$, with a $1 \mu \mathrm{m}$ 
$N_{\text {NON }}$ mode when Paris lies upwind, illustrating the lack of urban influence at PdD. The lack of sub- $2 \mu \mathrm{m}$ material in the size distributions is a combination of the clean environment at PdD and limited WIBS- 3 sensitivity at smaller sizes. The night-time $N_{\mathrm{NADH}}$ are associated with the residual layer/free troposphere and appear the most strongly during northeasterly air mass origins, which strongly suggests this material is transported aloft.

An aerosol mass spectrometer (Aerodyne, Inc) was operated at PdD from 18 to 28 June. Mass concentrations of up to $20 \mu \mathrm{g} \mathrm{m}^{-3}$ were recorded. A full description of the chemical composition measured by the AMS is described in Freney et al. (2011); however a brief summary is supplied here. Organic, sulphate, nitrate, ammonia and BC contributed $52 \%$, $21 \%, 10 \%, 12 \%$ and $5 \%$, respectively to the submicron non refractory mass. The submicron size distributions of all particles arriving at PdD indicate aged aerosol, with a major accumulation mode peak at $D_{\mathrm{A}}=600 \mathrm{~nm}$, and are characteristic of a background elevated site influenced by longrange transport. $\mathrm{NH}_{4}$ shows a strong correlation with $\mathrm{SO}_{4}$ $(r=0.87)$, and a weaker correlation with $\mathrm{NO}_{3}(r=0.53)$. The $\mathrm{NO}_{3}$ mass concentrations are larger at night than in the day, which indicates $\mathrm{NH}_{4} \mathrm{NO}_{3}$ formation that is likely related to increased gas-to-particle partitioning of ammonium nitrate favoured by the lower temperatures and higher relative humidity at night (Seinfeld and Pandis, 1998). The diurnal variation of the $\mathrm{NH}_{4}$ species remains relatively flat, while organic aerosol mass increases during the daytime hours.

The virtual potential temperatures calculated at PdD and at a lower altitude in Cézeaux (451 ma.s.l.) as described in Boulon et al. (2011) are well correlated during the experiment but differ by 10 to $20 \mathrm{~K}$ depending on the time of day. This offset exceeds the uncertainty on these measurements $(4.9 \mathrm{~K})$ and provides evidence that the two sites are in different, although connected, air masses. This situation can occur if the daytime boundary layer influences the nocturnal residual layer. This was reinforced by the low wind speeds at the summit (typically 2 to $5 \mathrm{~m} \mathrm{~s}^{-1}$ ), favouring blocked flow around the mountain.

\subsection{EFM, fluorescent and total aerosol concentrations}

The EFM results compare favourably with those obtained at remote locations by Harrison et al. (2005), Bauer et al. (2002) and Matthias-Maser et al. (2000) described earlier. Each of these previous studies reported total PBA concentration 1 to $50 \mathrm{~L}^{-1}$. They are also qualitatively consistent with these works, with bacteria dominating this number and fungal spores/yeasts contributing only a small fraction in each case and at PdD.

The majority of bacteria were found on the first impactor stage $\left(D_{50 \%}=9.9 \mu \mathrm{m}\right)$, and were observed to be 0.5 to $2 \mu \mathrm{m}$ in size under EFM; however, no detailed size analysis was performed. Two hypotheses could account for the size discrepancy. (1) The bacteria could be present in airborne clusters or on larger particles that break apart on impact, which is not uncommon (Lighthart, 2006). (2) Alternatively, the individual bacteria could have aerodynamic properties of larger particles. This would require very high density as the elongated shape of bacteria alone cannot account for the discrepancy.

Comparing the EFM and WIBS-3 data (Table 1), the mean $N_{\mathrm{NADH}}$ and bacteria count are both largest during impactor samples B and D, and both smallest during impactor C, which suggests total bacteria concentration may follow a diurnal cycle that peaks at night, while spore/yeast concentration is essentially unchanged throughout the day. Figure 6 shows the corresponding diurnal variation in temperature and relative humidity $(\mathrm{RH})$, where $\mathrm{RH}$ is at a maximum at night and temperature is at a minimum. This peak in RH correlates with the observed peak in bacteria concentration. The change in $N_{\mathrm{NADH}}$ and bacteria count between sample $\mathrm{C}$ and samples $\mathrm{B}$ and $\mathrm{D}$ were quite consistent: bacteria concentration changed by 20 to $30 \mathrm{~L}^{-1}$ (an order of magnitude larger than sample C), and $N_{\mathrm{NADH}}$ changed by 16 to $24 \mathrm{~L}^{-1}$ (a $\sim 20 \%$ increase cf. sample C). Mean $N_{\text {TRY }}$ was also calculated for each filter in Table 1 but varies independently of bacteria count and $N_{\mathrm{NADH}}$.

Impactor set A (a $24 \mathrm{~h}$ integration) does not support a link between measured bacteria concentration and observed $N_{\text {NADH }}$ increase at PdD, because it was sampled during one of the largest $N_{\mathrm{NADH}}$ rises of the campaign, which was not corroborated by the bacteria count at this time $\left(3.4 \mathrm{~L}^{-1}\right)$. If all the bacteria in sample A were collected during the $6 \mathrm{~h}$ of $N_{\mathrm{NADH}}$ enhancement on 25 to 26 June, the mean bacteria concentration at this time would be $14 \mathrm{~L}^{-1}$, still considerably less than that obtained during filter $\mathrm{C}$. It is therefore possible that the common nocturnal increases in bacteria and $N_{\mathrm{NADH}}$ are in fact a coincidence. The bacteria appear to have impaction properties of $10 \mu \mathrm{m}$ particles, so the possibility that they impact out of the air stream before reaching the WIBS-3 sensing volume must also be considered.

The APS reported number concentrations of 2 to $3.4 \mathrm{~L}^{-1}$ at $D_{\mathrm{A}} \geq 6.26 \mu \mathrm{m}$ throughout the impactor samples, and $N_{\mathrm{APS}}$ between 0.54 and $2 \mu \mathrm{m}$ decreases during impactor measurements. Non-bacterial aerosols (e.g. mineral dust or sea salt) were likely to dominate $N_{\mathrm{APS}}$ at 0.5 to $2 \mu \mathrm{m}$, but at larger sizes, $N_{\text {APS }}$ was small enough that a 20 to $30 \mathrm{~L}^{-1}$ increase in aerodynamically large bacteria would be clear. To reach $20 \mathrm{~L}^{-1}, N_{\text {APS }}$ must include all particles larger $3.79 \mu \mathrm{m}$, but this subset does not exhibit a strong change in concentration during filter samples B or D.

\subsection{The nature of the $\mathrm{N}_{\mathrm{NADH}}$ diurnal cycle}

The increases in $N_{\mathrm{NADH}}$ fraction appear to be a real feature of the aerosol rather than an instrument artefact since they do not occur as distinctly when northern France (including Paris) lies upwind, and no underlying cycle in the baseline fluorescence of the instrument was seen. The size of the 

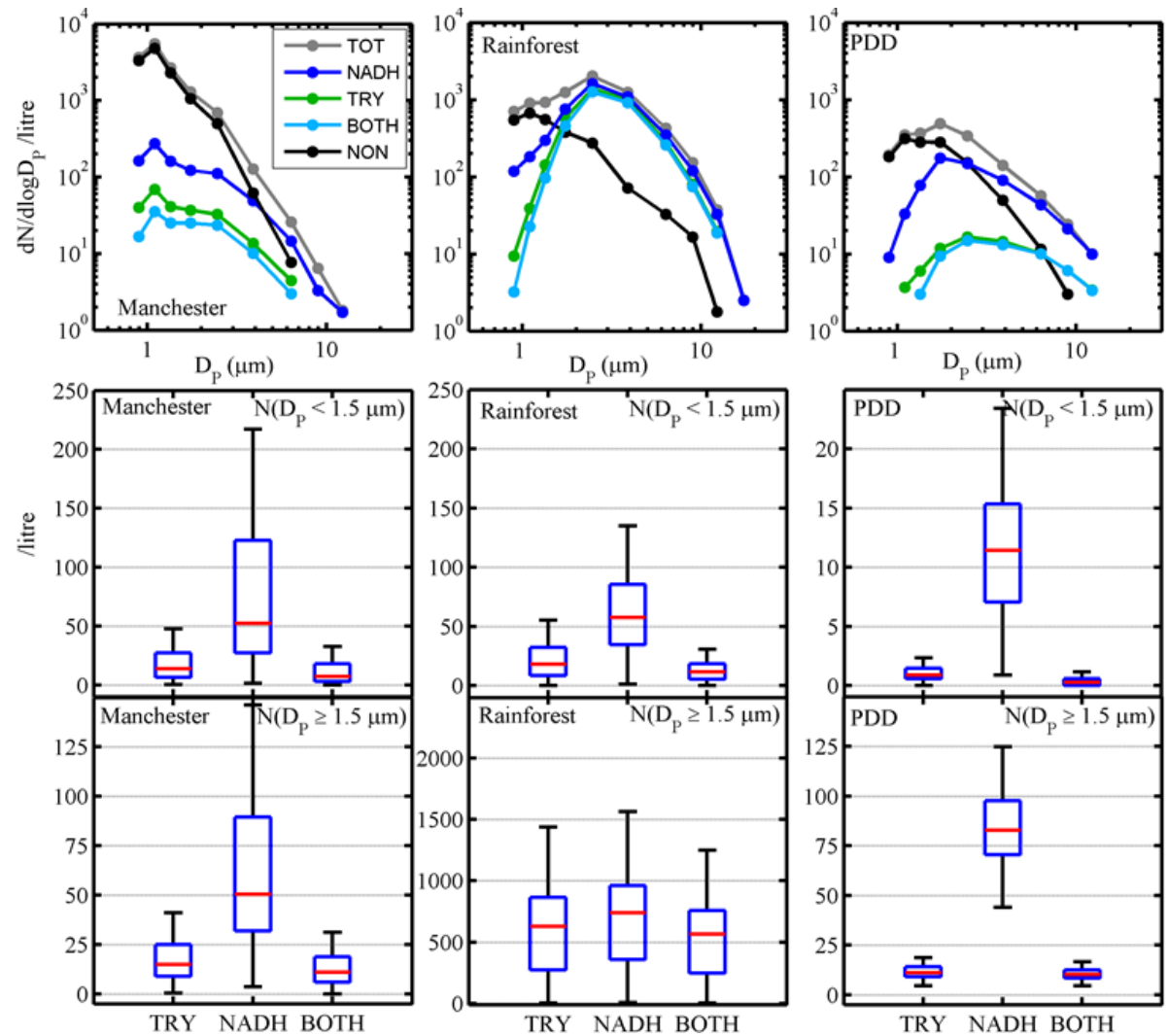

Fig. 5. Comparison of Puy de Dôme WIBS-3 data with Manchester, UK (urban), and beneath a tropical rainforest (Borneo, Malaysia). "Both" refers to particles fluorescent in the tryptophan and NADH channels.
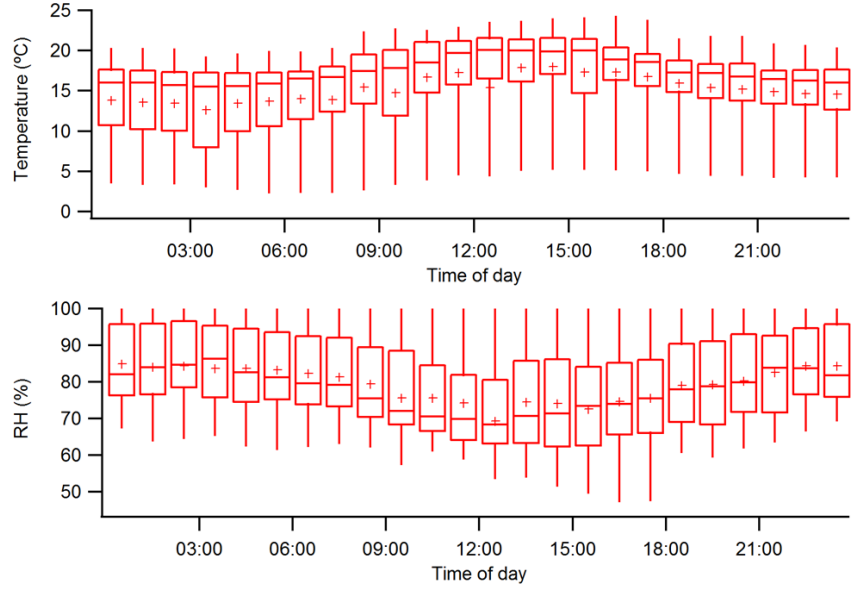

Fig. 6. Diurnal variation of temperature (top) and relative humidity (bottom) during the campaign period.

night-time increases in $N_{\mathrm{NADH}}$ and bacteria count are comparable on the two evenings for which there was data from both techniques, but if absolute $N_{\mathrm{NADH}}$ is compared directly with bacteria concentration, it would represent a large departure from the daytime EFM measurements obtained here and previously in published studies in most environments.
Strong tryptophan and weaker NADH peaks are frequently seen in bacteria fluorescence spectra (Hill et al., 2009), and $N_{\text {TRY }}$ would likely be larger if bacteria dominated the fluorescent aerosol. The relationship between $N_{\mathrm{NADH}}$ and $N_{\mathrm{TRY}}$ is also inconsistent with previous PBA measurements using the WIBS-3, both published and unpublished, where positive correlation was observed even when $N_{\mathrm{NADH}}$ and $N_{\mathrm{TRY}}$ differed significantly. Whilst fluorescence alone cannot categorically prove or disprove PBA status, these results do not support a conclusion that the $N_{\mathrm{NADH}}$ night-time increases at $\mathrm{PdD}$ are bacteria or fungal spores. Toprak and Schnaiter (2013) performed similar UV-LIF measurements using a WIBS-4 over the same period at a site in Germany. They attributed a correlation in $N_{\mathrm{NADH}}$ and $N_{\mathrm{TRY}}$ to local fungal spore release. The lack of correlation suggests that fungal spores are not dominant at this site at the time of measurement. Pollen is unlikely to be found in such concentrations, and filter analysis found there to be no pollen present. Based on the lack of systematic agreement between $N_{\mathrm{NADH}}$ and bacteria counts, the WIBS-3 dataset appears to offer an insight into the fluorescence of non-urban aerosol that was also not bacteria, fungal spores or pollen - the most numerous PBA types. It could include particles such as soil dust, partially decomposed bio- 
Table 3. Cluster averages for the WIBS3 dataset. Bottom row shows the number of constituent measurements. FL1 280, FL2 280 and FL2 370 are the intensities in each channel, respectively (arbitrary units).

\begin{tabular}{lrrr}
\hline & Cluster 1 & Cluster 2 & Cluster 3 \\
\hline FL1 280 & 107 & 1738 & 2092 \\
FL2 280 & 335 & 717 & 2003 \\
FL2 370 & 283 & 805 & 2027 \\
$D_{0}(\mu \mathrm{m})$ & 1.5 & 3.5 & 7.6 \\
AF & 13 & 33 & 22 \\
$\#$ & 10317 & 94 & 10 \\
\hline
\end{tabular}

logical material or possibly plant debris from intensive agricultural processes.

A hierarchical agglomerative cluster analysis technique was used on the WIBS-3 dataset to further probe the sampled particle types. Details of the technique are presented in Robinson et al. (2013). Due to the heavy computational burden, a random subset of the particles was used in the analysis ( $1 \%, \sim 10000$ particles), yielding a three-cluster solution, whose statistical parameters are summarised in Table 3. The remaining data was then attributed to a cluster by comparison to the cluster centroid as described by Robinson et al. (2013). Particles in cluster 1 were numerous and typically small $\left(D_{\mathrm{p}} \sim 1.5 \mu \mathrm{m}\right)$ with a small asymmetry factor and were non-fluorescent. Based on previous laboratory characterisations of the WIBS response to different aerosol types, cluster 1 is interpreted as being representative of the tail end of the ambient accumulation mode aerosol, and is likely comprised of various non-PBAP sources (Robinson et al., 2013). Cluster 2 identified particles where fluorescence in the FL1 280 channel dominated. Previous work by Gabey et al. (2011) (and references therein) showed bacteria (Pseudomonas syrengae and P. fluorescens) to fluoresce strongly in this channel. Several studies have also shown that aerosol containing culturable bacteria have diameters of approximately $4 \mu \mathrm{m}$ at several continental sites (Després et al., 2012; Wang et al., 2007; Tong and Lighthart, 2000). The mode size of cluster 2 particles was $3.5 \mu \mathrm{m}$, which is consistent with these studies. Additionally the particles in this cluster display high asymmetry factors, which is again consistent with bacterial aggregates. This strongly suggests that the particles in cluster 2 are representative of bacterial aggregates or some other particles associated with bacteria. Cluster 3 contains particles which are large, highly fluorescent in all channels and asymmetrical, suggesting that the particles are representative of pollen or yeast/fungal spores (Gabey et al., 2011). The EFM results reported earlier also confirm the presence of yeast/fungal spores at the site.

A time series of the cluster number concentrations is given in Fig. 7. Cluster 2 exhibits a diurnal cycle with a maximum in the afternoon. This is consistent with other studies which have shown peak culturable bacteria concentrations occur during the day (Shaffer and Lighthart, 1997), but is inconsistent with the impactor samples taken at the site which suggest the peak bacterial concentrations occur at night, or the study by Robinson et al. (2013) which also identified nocturnal maxima at an elevated pine forest site. However, it is possible that the majority of bacteria containing aerosol have been conflated into cluster 1 due to the limitations of the WIBS-3, such that cluster 2 contains only a subset of the total bacteria containing aerosol (Robinson et al., 2013). Peak concentrations are coincident with air masses from the northeast, while northern air masses are typically much lower in concentration, further demonstrating the lack of urban influence at PdD. Cluster 3 is unvarying throughout the period, suggesting that the cluster possibly associated with fungal spore/yeast concentration is consistently low at the site as discussed earlier. An average diurnal size distribution of cluster 2 is shown in Fig. 8, where it can be seen that the diameters lie between approximately 3 and $5 \mu \mathrm{m}$ throughout the day, but there is a significant broadening of the size distribution from approximately 09:00 until 22:00 LT, which coincides with increased number concentration. Figure 9 shows the average diurnal number concentrations of clusters 1 and 2 for the period of the NE air mass. Both clusters show a diurnal cycle with a maximum through the day with cluster 1 peaking around midday and cluster 2 (likely bacterial in nature) peaking around mid-afternoon. Cluster 3 has been omitted as it showed no cycle. It presented a constant baseline value of approximately $1 \mathrm{~L}^{-1}$ throughout the day, suggesting that the fungal spore/yeast consistent aerosol concentration at the site was constant.

PMF analysis of organic mass spectra measured by the AMS resolved two different types of organic compound. One represented a low-volatility oxidised organic aerosol (LVOOA) and the other a semi-volatile oxidised organic aerosol particle (SVOOA). The LVOOA is similar to oxidised organic aerosol measured in previous experiments (Ulbrich et al., 2009; Lanz et al., 2010; Slowik et al., 2010). This is mostly associated with aged organic particles having a dominant peak at $m / z 44$. The time series of LVOOA showed the strongest correlations with $\mathrm{O}_{3}\left(r^{2}=0.74\right), \mathrm{SO}_{4}^{2-}\left(r^{2}=0.41\right)$ and temperature $\left(r^{2}=0.83\right)$ as well as with $\mathrm{CO}$ and $\mathrm{BC}$ (0.67 and 0.65 , respectively). SVOOA contributed $25 \%$ to the overall organic mass, and its mass spectrum most closely resembled the published mass spectra of OOA2 (74\%; Ulbrich et al., 2009) and pinene (94\%; Bahreini et al., 2005). The mass concentrations of both organic components show a strong diurnal variation with maximum concentrations during the day and minima at night, but the fractal contribution of each species reveals a much higher contribution of LVOOA than SVOOA at night. This suggests that the organic aerosol is more aged at night than during the daytime, and is further evidence that the residual layer/free troposphere was sampled at night. 

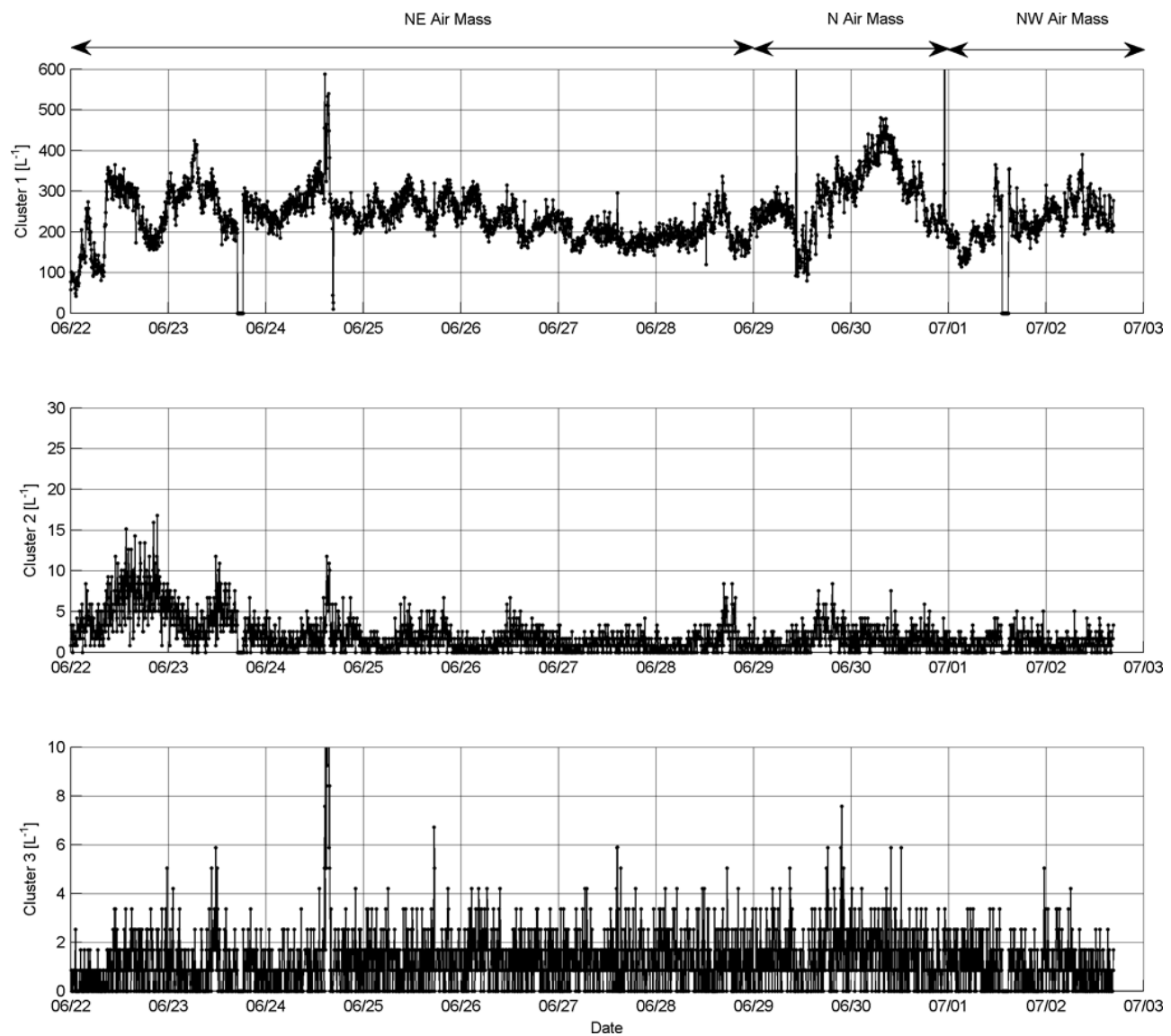

Fig. 7. Concentration time series of WIBS cluster analysis products with modelled air mass origin shown. Top to bottom show concentrations of clusters 1 to 3 , respectively $\left(\mathrm{L}^{-1}\right)$.

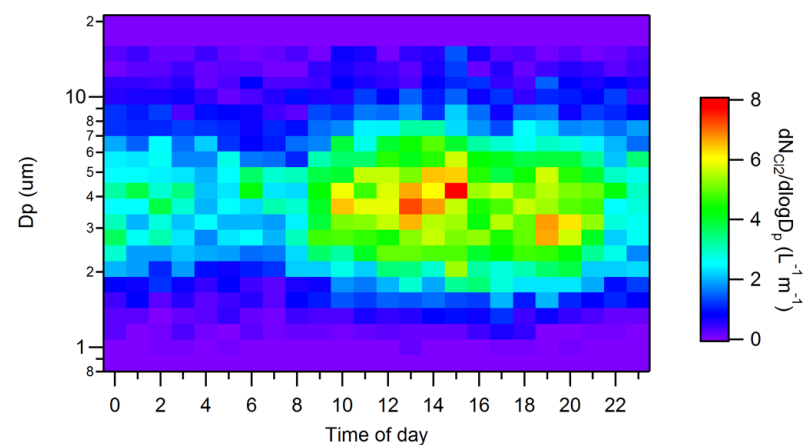

Fig. 8. Diurnal average size distribution of WIBS cluster 2 product of the period shown in Fig. 6.

Together the AMS and WIBS-3 data indicate that material with fluorescence similar to NADH was most abundant in the residual aerosol layer from 22 to 28 June. The nocturnal $N_{\text {NADH }}$ enhancements become less distinct after 28 June, when daytime $N_{\mathrm{NADH}}$ reaches a plateau following its gradual increase. After 28 June $N_{\mathrm{NADH}}$ is quite consistent, with one exception during the initial stages of the northerly influence.
It then returns to its previous value for the remainder of the campaign despite different air mass origins. The $N_{\mathrm{NADH}}$ enhancements therefore appear to be associated with northeasterly air masses. The underlying increase in $N_{\mathrm{NADH}}$ was slower than that of $N_{\mathrm{NON}}$ at the start of the campaign, suggesting $N_{\mathrm{NADH}}$ was also not produced in the vicinity of PdD.

\subsection{WIBS comparison with previous work}

Figure 5 compares the data from PdD (column 3) with that featured in Gabey et al. (2011) from an urban area (Manchester, UK) (Fig. 5, column 1) where fluorescent particles are likely to be dominated by fluorescent non-PBA, and within a tropical rainforest (Borneo) (Fig. 5, column 2) dominated by fungal spore emissions (Gabey et al., 2010). In Manchester, a primary mode at $1 \mu \mathrm{m}$ dominates the fluorescent and non-fluorescent number concentration. At 100 to $200 \mathrm{~L}^{-1}$, $N_{\mathrm{NADH}}$ at $D_{\mathrm{P}} \geq 1.5 \mu \mathrm{m}$ is comparable at Manchester and PdD, despite the fact that $N_{\text {TOT }}$ and $N_{\mathrm{APS}}$ are typically larger in Manchester than PdD in this size range.

With a 2 to $3 \mu \mathrm{m}$ mode, the PdD $N_{\mathrm{NADH}}$ size spectrum resembles the reported observations from the Borneo tropical forests more than Manchester. This is where the similarity 

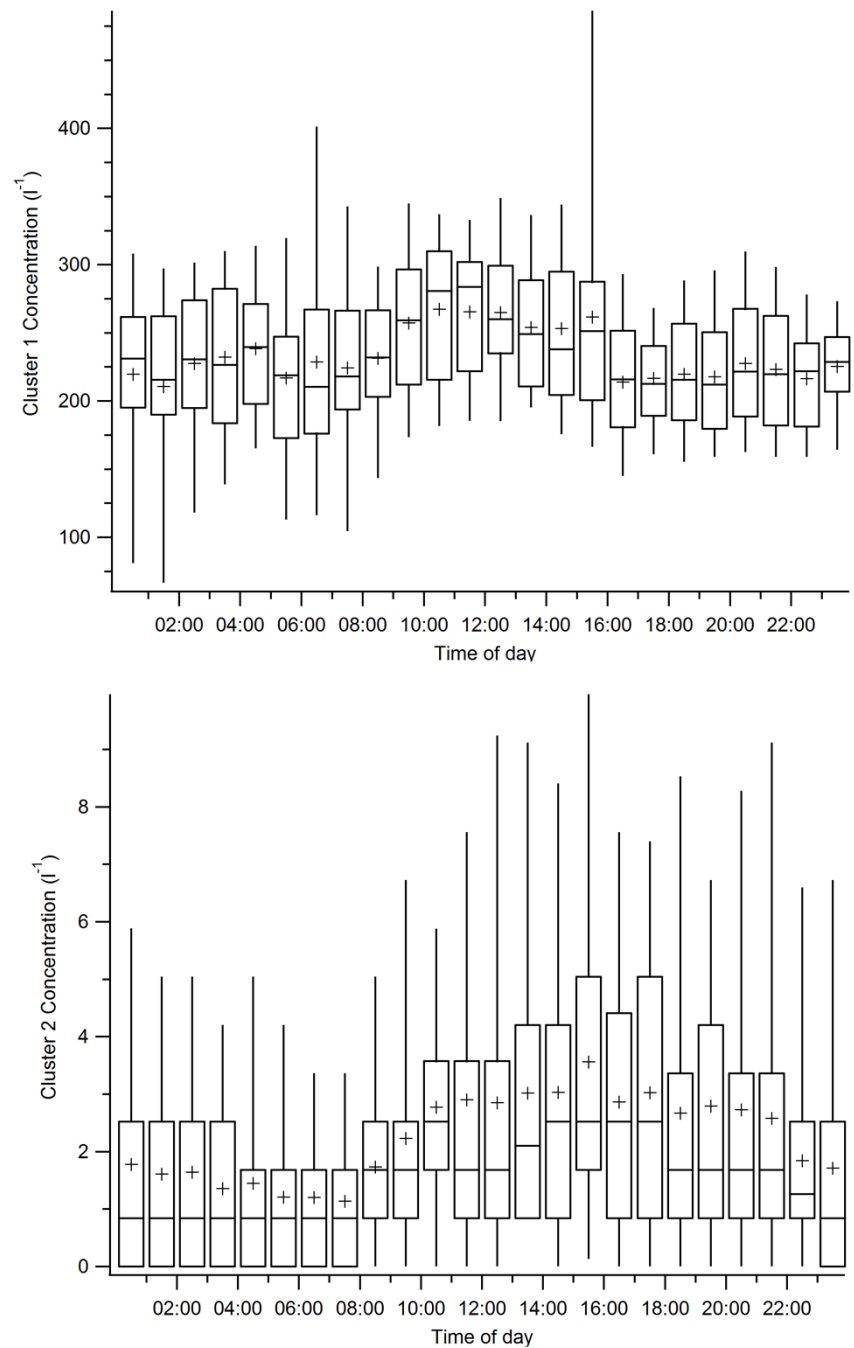

Fig. 9. Diurnal average number concentration of clusters 1 (top) and 2 (bottom) for the NE air mass time period. Mean values denoted with + sign.

ends, because $N_{\mathrm{NADH}} \approx N_{\mathrm{TRY}}$ in Borneo datasets whereas $N_{\mathrm{NADH}} \approx 10 N_{\mathrm{TRY}}$ at $\mathrm{PdD}$ and $N_{\mathrm{NADH}} \approx 3 N_{\mathrm{TRY}}$ in Manchester. $N_{\mathrm{NADH}}$ and $N_{\mathrm{TRY}}$ in Manchester and Borneo are usually correlated positively; however, they are regularly anticorrelated at PdD, suggesting a different type of fluorescent aerosol dominates.

\section{Conclusions}

Increased $N_{\mathrm{NADH}}$ and aged organic aerosol in the residual layer suggest that a surprisingly large concentration of fluorescent aerosol sized 2 to $3 \mu \mathrm{m}$ was transported aloft in air masses associated with NE France. The relatively slow increase in underlying $N_{\mathrm{NADH}}$ and its independence from air mass origin indicate a ubiquitous background. Since the campaign was held in summer 2010 there may be a seasonal agricultural contribution.

Bacteria concentrations at $\mathrm{PdD}$ were 3 to $33 \mathrm{~L}^{-1}$ and fungal spore/yeast concentrations ranged from 0.8 to $2.7 \mathrm{~L}^{-1}$, comparable to previous measurements at high-altitude and remote sites. Concentration of "tryptophan-like" containing material concentrations, $N_{\mathrm{TRY}}$, averaged $12 \mathrm{~L}^{-1}$ (less than $10 \%$ of $\left.N_{\mathrm{NADH}}\right)$ and did not exhibit the same diurnal variations as "NADH-like" aerosol, $N_{\mathrm{NADH}}$, or bacteria count. This is not surprising given bacteria were measured on the first $\left(D_{50 \%}=9.9 \mu \mathrm{m}\right)$ and second $\left(D_{50 \%}=6.8 \mu \mathrm{m}\right)$ impactor stages whereas the $N_{\text {TRY }}$ modal size was $3 \mu \mathrm{m}$. There is insufficient information to determine whether this channel was more or less likely to be PBA. Cluster analysis yielded a distinct group of particles that was consistent with bacteria and which exhibited a diurnal cycle with a maxima in the daytime, coinciding with a broadening of the cluster size distribution. It is possible that this cluster is only representative of a subset of the aerosol which contain bacteria and not the total population of aerosol which contain bacteria as some of these bacterial aerosol may have been conflated into cluster 1 , which may explain the discrepancy in the diurnal maxima Robinson et al. (2013).

Two sub-populations of $N_{\mathrm{NADH}}$ could be distinguished based on the WIBS-3 AF (shape) channel. Low-AF material was seen during enhancements and high-AF during the day. The $N_{\text {NADH }}$ size mode was slightly smaller at night, indicating that the fraction of $N_{\mathrm{NADH}}$ found in the residual layer has different properties to that observed in the daytime. It has been demonstrated in the laboratory that some Bacillus spores can grow and shrink in response to changes in relative humidity (Westphal et al., 2003), although these changes are usually much smaller than the precision of the optical sizing technique used here.

Since an urban influence is not detected, this dataset is a good example of the fluorescent background aerosol found at the top of the boundary layer and in the residual layer in continental locations. The abundance and optical equivalent diameter of this material is surprisingly large and is comparable to the total concentration in the size range $0.8 \leq D_{\mathrm{P}} \leq 20 \mu \mathrm{m}$. Data from other seasons is not available, and this may be a summer phenomenon.

To our knowledge, no other similar studies concerning fluorescent aerosol at altitude exist in the published literature, and the additional fluorescent concentration found in the residual layer/free troposphere was surprisingly large (up to $100 \mathrm{~L}^{-1}$ in excess of that found during the daytime). This may offer a partial explanation of why $N_{\mathrm{NADH}}$ was greater than $N_{\mathrm{TRY}}$ in previous WIBS-3 measurement campaigns. It is also clear that much more effort is needed by the community in order to provide a systematic and comprehensive comparison between offline analysis techniques for biological particles and real-time continuous UV-LIF techniques so that a fuller understanding of atmospheric dispersion of these particles and their fluxes can be gained. 
Acknowledgements. This work was supported by a $\mathrm{PhD}$ studentship funded by the UK Natural Environment Research Council (award NE/F00866X/1) and by the NERC-funded contribution to the US BEACHON project (NE/H019049/1).

Edited by: H. Su

\section{References}

Allan, J. D., Delia, A. E., Coe, H., Bower, K. N., Alfarra, M., Jimenez, J. L., Middlebrook, A. M., Drewnick, F., Onasch, T. B., Canagaratna, M. R., Jayne, J. T., and Worsnop, D. R.: A generalised method for the extraction of chemically resolved mass spectra from Aerodyne aerosol mass spectrometer data, J. Aerosol Sci., 35, 909-922, doi:10.1016/j.jaerosci.2004.02.007, 2004.

Aptowicz, K. B., Pinnick, R. G., Hill, S. C., Pan, Y. L., and Chang, R. K.: Optical scattering patterns from single urban aerosol particles at Adelphi, Maryland, USA: A classification relating to particle morphologies, J. Geophys. Res., 111, D12212, doi:10.1029/2005JD006774, 2006.

Bahreini, R., Keywood, M. D., Ng, N. L., Varutbangkul, V., Gao, S., Flagan, R. C., Seinfeld, J. H., Worsnop, D. R., and Jimenez, J. L.: Measurements of Secondary Organic Aerosol from Oxidation of Cycloalkenes, Terpenes, and $\mathrm{m}$-Xylene Using an Aerodyne Aerosol Mass Spectrometer, Environ. Sci. Technol., 39, 56745688, doi:10.1021/es048061a, 2005.

Bauer, H., Kasper-Giebl, A., Löflund, M., Giebl, H., Hitzenberger, R., Zibuschka, F., and Puxbaum, H.: The contribution of bacteria and fungal spores to the organic carbon content of cloud water, precipitation and aerosols, Atmos. Res., 64, 109-119, doi:10.1016/S0169-8095(02)00084-4, 2002.

Bauer, H., Schueller, E., Weinke, G., Berger, A., Hitzenberger, R., Marr, I. L., and Puxbaum, H.: Significant contributions of fungal spores to the organic carbon and to the aerosol mass balance of the urban atmospheric aerosol, Atmos. Environ., 42, 5542-5549, doi:10.1016/j.atmosenv.2008.03.019, 2008.

Boulon, J., Sellegri, K., Hervo, M., Picard, D., Pichon, J.-M., Fréville, P., and Laj, P.: Investigation of nucleation events vertical extent: a long term study at two different altitude sites, Atmos. Chem. Phys., 11, 5625-5639, doi:10.5194/acp-11-56252011, 2011.

Canagaratna, M. R., Jayne, J. T., Jimenez, J. L., Allan, J. D., Alfarra, M. R., Zhang, Q., Onasch, T. B., Drewnick, F., Coe, H., Middlebrook, A., Delia, A., Williams, L. R., Trimborn, A. M., Northway, M. J., DeCarlo, P. F., Kolb, C. E., Davidovits, P., and Worsnop, D. R.: Chemical and microphysical characterization of ambient aerosols with the aerodyne aerosol mass spectrometer., Mass Spectr. Rev., 26, 185-222, doi:10.1002/mas.20115, 2007.

DeCarlo, P. F., Kimmel, J. R., Trimborn, A., Northway, M. J., Jayne, J. T., Aiken, A. C., Gonin, M., Fuhrer, K., Horvath, T., Docherty, K. S., Worsnop, D. R., and Jimenez, J. L.: Field-deployable, high-resolution, time-of-flight aerosol mass spectrometer., Anal. Chem., 78, 8281-9, doi:10.1021/ac061249n, 2006.

Després, V. R., Alex Huffman, J., Burrows, S. M., Hoose, C., Safatov, A. S., Buryak, G., Fröhlich-Nowoisky, J., Elbert, W., Andreae, M. O., Pöschl, U., and Jaenicke, R.: Primary biological aerosol particles in the atmosphere: a review, Tellus B, 64, 15598, doi:10.3402/tellusb.v64i0.15598, 2012.
Eduard, W.: Recognition errors in the quantification of microorganisms by fluorescence microscopy, Ann. Occupat. Hygiene, 45, 493-498, doi:10.1093/annhyg/45.6.493, 2001.

Eduard, W. and Heederik, D.: Methods for quantitative assessment of airborne levels of noninfectious microorganisms in highly contaminated work environments., American Industrial Hygiene Association journal, 59, 113-27, doi:10.1080/15428119891010370, http://www.ncbi.nlm.nih.gov/pubmed/9487665, 1998.

Eng, J., Lynch, R. M., and Balaban, R. S.: Nicotinamide adenine dinucleotide fluorescence spectroscopy and imaging of isolated cardiac myocytes, Biophysical J., 55, 621-30, doi:10.1016/S0006-3495(89)82859-0, 1989.

Foot, V. E., Kaye, P. H., Stanley, W. R., Barrington, S. J., Gallagher, M., and Gabey, A.: Low-cost real-time multiparameter bioaerosol sensors, Optically Based Biological and Chemical Detection for Defence, 71160I-71160I-12, doi:10.1117/12.800226, 2008.

Freney, E. J., Sellegri, K., Canonaco, F., Boulon, J., Hervo, M., Weigel, R., Pichon, J. M., Colomb, A., Prévôt, A. S. H., and Laj, P.: Seasonal variations in aerosol particle composition at the puy-de-Dôme research station in France, Atmos. Chem. Phys., 11, 13047-13059, doi:10.5194/acp-11-13047-2011, 2011.

Gabey, A. M., Gallagher, M. W., Whitehead, J., Dorsey, J. R., Kaye, P. H., and Stanley, W. R.: Measurements and comparison of primary biological aerosol above and below a tropical forest canopy using a dual channel fluorescence spectrometer, Atmos. Chem. Phys., 10, 4453-4466, doi:10.5194/acp-10-4453-2010, 2010.

Gabey, A. M., Stanley, W. R., Gallagher, M. W., and Kaye, P. H.: The fluorescence properties of aerosol larger than $0.8 \mu \mathrm{m}$ in urban and tropical rainforest locations, Atmos. Chem. Phys., 11, 5491-5504, doi:10.5194/acp-11-5491-2011, 2011.

Harrison, R. M., Jones, A. M., Biggins, P. D. E., Pomeroy, N., Cox, C. S., Kidd, S. P., Hobman, J. L., Brown, N. L., and Beswick, A.: Climate factors influencing bacterial count in background air samples., Int. J. Biometeorol., 49, 167-78, doi:10.1007/s00484004-0225-3, 2005.

Hill, S. C., Mayo, M., and Chang, R. K.: Fluorescence of Bacteria, Pollens, and Naturally Occurring Airborne Particles: Excitation/Emission Spectra, Lightning Source UK Ltd, 2009.

Huffman, J. A., Treutlein, B., and Pöschl, U.: Fluorescent biological aerosol particle concentrations and size distributions measured with an Ultraviolet Aerodynamic Particle Sizer (UVAPS) in Central Europe, Atmos. Chem. Phys., 10, 3215-3233, doi:10.5194/acp-10-3215-2010, 2010.

Kaye, P. H., Stanley, W. R., Hirst, E., Foot, E. V., Baxter, K. L., and Barrington, S. J.: Single particle multichannel bio-aerosol fluorescence sensor, Optics Express, 13, 3583, doi:10.1364/OPEX.13.003583, 2005.

Lakowicz, J. R.: Principles of Fluorescence Spectroscopy, Springer, New York, 3rd Edn., 2006.

Lanz, V. A., Prévôt, A. S. H., Alfarra, M. R., Weimer, S., Mohr, C., DeCarlo, P. F., Gianini, M. F. D., Hueglin, C., Schneider, J., Favez, O., D’Anna, B., George, C., and Baltensperger, U.: Characterization of aerosol chemical composition with aerosol mass spectrometry in Central Europe: an overview, Atmos. Chem. Phys., 10, 10453-10471, doi:10.5194/acp-10-10453-2010, 2010.

Li, J. K. and Humphrey, A. E.: Use of fluorometry for monitoring and control of a bioreactor., Biotechnol. Bioeng., 37, 1043-9, 
doi:10.1002/bit.260371109, 1991.

Lighthart, B.: The ecology of bacteria in the alfresco atmosphere, FEMS Microbiol. Ecol., 23, 263-274, doi:10.1111/j.15746941.1997.tb00408.x, 2006.

Marinoni, A., Laj, P., Sellegri, K., and Mailhot, G.: Cloud chemistry at the Puy de Dôme: variability and relationships with environmental factors, Atmos. Chem. Phys., 4, 715-728, doi:10.5194/acp-4-715-2004, 2004.

Matthias-Maser, S. and Jaenicke, R.: The size distribution of primary biological aerosol particles with radii $; 0.2 \mu \mathrm{m}$ in an urban/rural influenced region, Atmos. Res., 39, 279-286, doi:10.1016/0169-8095(95)00017-8, 1995.

Matthias-Maser, S., Bogs, B., and Jaenicke, R.: The size distribution of primary biological aerosol particles in cloud water on the mountain Kleiner Feldberg/Taunus (FRG), Atmos. Res., 54, 113, doi:10.1016/S0169-8095(00)00039-9, 2000.

Merola, S., Gambi, G., Allouis, C., Beretta, F., Borghese, A., and D'Alessio, A.: Analysis of exhausts emitted by i.c. engines and stationary burners, by means of u.v. extinction and fluorescence spectroscopy, Chemosphere, 42, 827-834, doi:10.1016/S00456535(00)00257-5, 2001.

Pan, Y.-L., Pinnick, R. G., Hill, S. C., Rosen, J. M., and Chang, R. K.: Single-particle laser-induced-fluorescence spectra of biological and other organic-carbon aerosols in the atmosphere: Measurements at New Haven, Connecticut, and Las Cruces, New Mexico, J. Geophys. Res., 112, D24S19, doi:10.1029/2007JD008741, 2007.

Porter, K. G. and Feig, Y. S.: The use of DAPI for identifying and counting aquatic microflora, Limnol. Oceanogr., 25, 943-948, doi:10.4319/lo.1980.25.5.0943, 1980.

Robinson, N. H., Allan, J. D., Huffman, J. A., Kaye, P. H., Foot, V. E., and Gallagher, M.: Cluster analysis of WIBS single-particle bioaerosol data, Atmos. Meas. Tech., 6, 337-347, doi:10.5194/amt-6-337-2013, 2013.

Seinfeld, J. H. and Pandis, S. N.: Atmospheric Chemistry and Physics: From Air Pollution to Climate Change, John Wiley \& Sons, Inc, New York, 1998.
Sellegri, K., Laj, P., Marinoni, A., Dupuy, R., Legrand, M., and Preunkert, S.: Contribution of gaseous and particulate species to droplet solute composition at the Puy de Dôme, France, Atmos. Chem. Phys., 3, 1509-1522, doi:10.5194/acp-3-1509-2003, 2003.

Shaffer, B. and Lighthart, B.: Survey of Culturable Airborne Bacteria at Four Diverse Locations in Oregon: Urban, Rural, Forest, and Coastal, Microbial Ecology, 34, 167-177, doi:10.1007/s002489900046, 1997.

Slowik, J. G., Vlasenko, A., McGuire, M., Evans, G. J., and Abbatt, J. P. D.: Simultaneous factor analysis of organic particle and gas mass spectra: AMS and PTR-MS measurements at an urban site, Atmos. Chem. Phys., 10, 1969-1988, doi:10.5194/acp-10-19692010, 2010.

Tong, Y. and Lighthart, B.: The Annual Bacterial Particle Concentration and Size Distribution in the Ambient Atmosphere in a Rural Area of the Willamette Valley, Oregon, Aerosol Sci. Technol., 32, 393-403, doi:10.1080/027868200303533, 2000.

Toprak, E. and Schnaiter, M.: Fluorescent biological aerosol particles measured with the Waveband Integrated Bioaerosol Sensor WIBS-4: laboratory tests combined with a one year field study, Atmos. Chem. Phys., 13, 225-243, doi:10.5194/acp-13225-2013, 2013.

Ulbrich, I. M., Canagaratna, M. R., Zhang, Q., Worsnop, D. R., and Jimenez, J. L.: Interpretation of organic components from Positive Matrix Factorization of aerosol mass spectrometric data, Atmos. Chem. Phys., 9, 2891-2918, doi:10.5194/acp-9-2891-2009, 2009.

Venzac, H., Sellegri, K., Villani, P., Picard, D., and Laj, P.: Seasonal variation of aerosol size distributions in the free troposphere and residual layer at the puy de Dôme station, France, Atmos. Chem. Phys., 9, 1465-1478, doi:10.5194/acp-9-1465-2009, 2009.

Wang, H., Reponen, T., Lee, S.-A., White, E., and Grinshpun, S. A.: Size distribution of airborne mist and endotoxin-containing particles in metalworking fluid environments., J. Occupat. Environ. Hygiene, 4, 157-65, doi:10.1080/15459620601144883, 2007.

Westphal, A. J., Price, P. B., Leighton, T. J., and Wheeler, K. E.: Kinetics of size changes of individual Bacillus thuringiensis spores in response to changes in relative humidity., Proc. Natl. Acad USA, 100, 3461-6, doi:10.1073/pnas.232710999, 2003. 